\title{
Kim Sterelny's Dawkins vs. Gould: Survival of the Fittest
}

\section{Leonard Finkelman}

Published online: 12 February 2008

(C) Springer Science + Business Media, LLC 2008

It isn't worth my while to debate every ambitious Darwinist who wants to try hard at ridiculing the opposition, so my general policy is that Darwinists have to put a significant figure at risk before I will agree to a debate. That means specifically [Richard] Dawkins or [Stephen Jay] Gould, or someone of like stature and public visibility.

So wrote Phillip E. Johnson, former University of California at Berkeley law professor and founder of the "Intelligent Design" movement, in April 2001. Had either Dawkins or Gould met his challenge, it would have been a coup for the then-decade-old movement. After all, such well-respected minds would only entertain the most serious of challenges. Intelligent Design (ID) theorists could therefore claim some measure of victory by having the debate at all; however, because of their respective pedigrees, Dawkins or Gould would be held to higher standards. For precisely that reason, the two biologists resolved to deny Johnson and his supporters their desired platform: in a draft of an open letter to be co-signed by Gould, Dawkins responded, “...we shall cultivate our evolutionary gardens, occasionally engaging in the more exacting and worthwhile task of debating each other." (This episode is recounted in Dawkins' collection of short works, "A Devil's Chaplain," in the essay entitled "Unfinished Correspondence with a Darwinian Heavyweight.")

\footnotetext{
L. Finkelman $(\square)$

City University of New York Graduate Center,

New York, NY, USA

e-mail: 1finkelman@gc.cuny.edu
}

The task may not only be an exacting and worthwhile one, but also one to inflame intellectual passions and fuel an academic rivalry.

The history of science - which is, after all, a history of all-too-human scientists - is replete with conflict. Recall how Newton antagonized Leibniz over the nature of space; imagine how the sparks must have flown when Einstein took Bohr and his nascent quantum theory to task. When it was at its most heated, the feud between Dawkins and Gould was waged as publicly as scientific debate may be. Their exchanges played out in the pages of such widely circulated periodicals as the New York Review of Books, to say nothing of each theorist's own best-selling popular works. As a result, even a marginally informed layperson would have been aware of the debate's existence, if not its details.

Unfortunately, it is in the details that the DawkinsGould debate differs from those other well-known academic feuds, and this has been a source of trouble for evolutionary biology in general. The popular model of a scientific debate is that of a zero-sum game: The triumph of one party demands repudiation of the other. Space and time are either absolute quantities or not; quantum mechanics is either true or false. It is perhaps for this reason that Johnson and his Intelligent Design ilk have placed so much emphasis on Dawkins and Gould. After all, if one well-respected biologist follows Darwin and another equally well-respected biologist disagrees with the first, then there can hardly be consensus about the validity of evolutionary theory. Nevertheless, the exchange between Dawkins and Gould does not fit this misconceived winner-takes-all form. 
It is therefore to his credit that Kim Sterelny opens his survey of the debate, entitled Dawkins vs. Gould: Survival of the Fittest, with an explanation of what Dawkins and Gould hold in common, proceeding to what is at stake for the opponents only after laying out what is taken for granted. Both are avowed disciples of Darwin and his theory of evolution by means of natural selection. Both have defended the idea that, within any population whose reproductive rate outstrips its means of survival, advantageous traits inherited genetically will tend to be preserved. Both agree that, given a geological timescale, these preserved traits will eventually accumulate in new forms of life. Where the two differ is in their interpretations of natural selection's scope and meaning.

Proceeding through Dawkins vs. Gould one may be struck by how often these antagonists (described in the book's back cover as being engaged in a "savage battle") accommodate one another. With few exceptions, each chapter follows a similar pattern: a summary of the biological facts followed by a survey of the combatants' common ground and the point of departure taken by one from the other. Far from homogenizing the titular figures, however, this approach ultimately serves to give a clear summary of the distinct intellectual spaces they occupy. Those readers who enter into the text lacking knowledge of either figure's works will find excellent summaries of the broad trends in each career.

What follows is a sort of "greatest hits" compilation. From The Selfish Gene, The Extended Phenotype and The Blind Watchmaker Sterelny draws out the concepts central to Dawkins' view of biology. Dawkins has built his career upon the foundations of his selfish gene theory, wherein biology is cast as a mechanistic system similar to one of the physical sciences. The treatment given in this paper illustrates how it is possible that even the most complex organic traits might be explained in terms of the slow, steady action of simple laws (natural selection) upon the system's most basic components (genes). This so-called gene's eye view of evolution is contrasted with that of Gould, as distilled from such works as Wonderful Life, Full House, and The Structure of Evolutionary Theory. Gould's central themes of contingency and diversity create a view of biology in which the constant pace of natural selection may be perturbed by the vagaries of a chaotic environment. Whereas the nuance of Gould's evolutionary theory might come across as more complicated than Dawkins' to a neophyte, Sterelny keeps his descriptions of each concept as clear and uncomplicated as possible.

Sterelny's success in isolating the essential points of contention between Dawkins and Gould follows from an important insight into their debate: It is, for the most part, less over science than it is over philosophy (it comes as no surprise that Sterelny is himself a professor of philosophy at Victoria University in Wellington). He writes that the arguments between the two "within evolutionary theory are exacerbated by different assessments of science itself" (p. 14). Dawkins, the consummate Oxford scientist, sees science as an all-encompassing reductionist program; Gould, a polymath equally comfortable writing about such disparate subjects as DiMaggio-era baseball and Cambrian-era trilobites, takes a more limited view of science as on a par with other modes of knowledge.

This dichotomy, as drawn by Sterelny, is largely accurate but has the potential to ultimately become a part of a larger problem. At one point he writes that Gould built his career "arguing for the existence of large-scale patterns...not explained by natural selection" (p.79). One will never find in Gould's work the claim that natural selection is insufficient to the task of explaining biological phenomena. Rather, Gould's emphasis is on the claim that its sufficiency ought not to be overextended to explain phenomena for which it is unnecessary; he often cautions against thinking of all organic properties as adaptive. Sterelny does consider these ideas, particularly in his chapter entitled "Selection and Adaptation," but mostly as contrasted with the "adaptationist" leanings of the "ultraDarwinist" Dawkins. If this is the sort of locution that might inspire pumped fists and gleeful cheers from the aforementioned Intelligent Design theorists, it is only because it is so easily misread.

Perhaps, because of the summary nature of his survey, Sterelny sometimes seems to cast Dawkins and Gould in the roles created for them in the ID misrepresentation of their debate, despite his efforts to paint both biologists with the same Darwinian brush. In particular, to cast Gould as opposed to some 'ultra-Darwinian' orthodoxy, absent the proper context, has the potential to lead to such foolishness as that found on Creationist websites that claim Gould as a closeted champion of their cause. Dawkins is only more Darwinian than Gould insofar as he is more Darwinian than Darwin himself; where the father of modern biology saw natural selection as the "main but not exclusive" mechanism for evolutionary change (as written in The Origin of Species), Dawkins sees selection as an agent that is both exclusive and universal. Gould's rejection of this extension of Darwin's theory does not entail rejection of that theory's core. The absence of this explicit clarification from Sterelny's book may lead to misunderstanding for those readers whose preconceptions of this debate have been shaped by a media uncritical of the ID theorists' account. This is a minor issue overall; however, given the historical context of the relevant debate, it is one that the lay reader ought to bear in mind.

Notwithstanding this fault, Sterelny's Dawkins vs. Gould is a worthwhile read on several levels. For those 
whose interest in evolutionary biology has not yet carried them into the field's contemporary discourse, the book not only gives a clear and accurate summary of the subjects' corpora but also points the way towards where to turn next. Sterelny's extensive list of suggested readings should also prove useful to more advanced readers, many of whom will benefit from the conceptual clarity provided by Sterelny's review of the material. Even as the titular clash of personalities has, sadly, had its final chapter written, Sterelny's book should serve as the starting point for those inspired to carry on the clash of ideas. 